\title{
Stress level of physical education students: How the learning process during the covid-19 pandemic?
}

\author{
Apta Mylsidayu \\ Universitas Islam 45 Bekasi, Indonesia
}

Received: 24 November 2020; Accepted 08 February 2021; Published 25 March 2021

Ed 2021; 6(1): 119-129

\begin{abstract}
Many physical education students complain that online lectures are unsatisfactory because they do not practice directly (only theory). Students feel not really understand the material presented because study with offline and online is different, and lecture assignments are piling up so that causing physical education students to become boredom and stressed. This study aims to determine the level stress of college students during the COVID-19 pandemic. Quantitative descriptive is the method used in this research, with a total sample of 168 student used accidental sampling techniques. Measurement the level of stress is using The Kessler Psychological Distresss Scale (K10) which is distributed via Google form. Data analysis used is quantitative description analysis techniques with percentages. The results show that the stress level of physical education students is in the heavy category of $34 \%$ (58 people). So, students can manage stress by stress coping, managing stress, doing physical activity, thinking positively, and doing self-talk.
\end{abstract}

Keywords: Stress; physical education; covid-19; pandemic

d.

https://doi.org/10.25299/sportarea.2021.vol6(1).5279

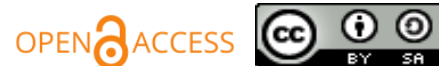

Copyright (C) 2021 Apta Mylsidayu

Corresponding author: Apta Mylsidayu, Physical Education Health and Recreation, Universitas Islam 45 Bekasi, Bekasi, Jawa Barat, Indonesia

Email: mylsidayu@gmail.com

How To Cite: Mylsidayu, A. (2021). Stress level of physical education students: How to do the learning during the covid-19 pandemic?. Journal Sport Area, 6(1), 119-129. https://doi.org/10.25299/sportarea.2019.vol6(1).5729

\section{INTRODUCTION}

The world is experiencing a Covid-19 pandemic. Pandemics are used to indicate outbreaks of new pathogens that spread easily to everyone around the world (Nebehay, 2020). Covid-19 stands for Coronavirus Disease 2019, a new type of disease that has never been previously identified in humans (Kemenkes RI, 2020). The World Health Organization (WHO) has designated 11 February 2020 as a global pandemic (Putri, 2020), and has shown that more than 43,000 confirmed cases have been identified in 28 countries / regions, with $>99 \%$ of cases detected in China (Lai, Shih, Ko, Tang, \& Hsueh, 2020). The Covid19 disease outbreak has become a major threat to public health in China, with a high infectious capacity and variable mortality (Lian, Jiangshan, Jin, Xi, Hao, Shaorui, Cai, Huan, Zhang, 2020). WHO states that 16$21 \%$ of people with the COVID-19 virus in China are seriously ill with a mortality rate of 2-3\% (Wang et al., 2020).

Covid-19 is an emerging disease, therefore more efforts are needed to improve prevention, diagnosis and treatment strategies (Xu et al., 2020). Data on covid-19 cases in Indonesia as of February 5, 2021, it is known that the number of positives exposed to Covid-19 was 1,134,854 people, the number of patients recovered was 926,980 people, and the number of cases died was 31,202 people (Komite Penanganan Covid-19 dan Pemulihan Ekonomi Nasional, 2021). Based on these data, cases of the spread of Covid -19 in 
Indonesia are increasing day by day, so the government has decided to implement work from home, which is one of the strategies to prevent the spread of Covid -19 to break the chain of Covid -19 .

Universitas Islam 45 Bekasi also implements work from home as one of the supports for the government's decision. Lectures are conducted online, including students in the Physical Education Study Program. However, there are several complaints from physical education students regarding online lectures, including: (1) do not understand the material delivered online, (2) do not understand the assignments given by the lecturer, (3) feel bored and stress because of piling up college assignments.

The results of the study Sadikin and Hamidah (2020) states that the lack of supervision of students, difficulty in getting signals in remote areas and the high cost of quotas are challenges in online learning. Findings Setiyawan, Kresnapati, and Setiawan (2020) regarding the analysis of online lectures for PJKR students at the PGRI University of Semarang as a result of the COVID-19 pandemic states that the readiness of students is quite ready at $52.4 \%$, and the biggest obstacle for students was challenging the signal by $58.9 \%$.

Lecture barriers can cause academic stress. Academic stress is a subjective perception of an academic condition or a response experienced by students in the form of negative physical reactions, behaviors, thoughts, and emotions that arise due to academic demands (Barseli \& Ifdil, 2017). Academic stress can reduce academic achievement, reduce motivation, and increase the risk of dropping out of school (Pascoe Hetrick, \& Parker, 2020).

Stress is one of the most significant health problems in modern society and the 21 st century (Kudielka \& Wüst, 2010), the feeling experienced by an individual when facing stress (Ananda \& Apsari, 2020), a response of one's body that arises as a reaction to there are external demands that are considered dangerous or threatening (Legiran, Azis, \& Belinawati, 2015). In particular, stress can have a negative impact on learning conditions and cognitive abilities (Gaol, 2016). That is, when a person experiences stress it will indirectly affect the performance of the brain to concentrate, namely the ability to maintain focus on activities in an environment or learning environment (Tangkudung \& Mylsidayu, 2017). If they postpone doing important activities so they become urgent, it can increase stress levels (Rusdi, 2015).

The symptoms of stress consist of: (1) physical symptoms, including headaches, palpitations, changes in diet, weak, frequent urination, and difficulty swallowing, (2) emotional symptoms, including depression, irritable, moody, anxious, worried, easy to cry, anxious about small things, panic, and behaving impulsively, and (3) behavioral symptoms, including frowning, aggressive actions, tendency to be alone, careless, blaming others, daydreaming, high pitched restless laughter, pacing, and changing social behavior (Barseli \& Ifdil, 2017). Strengthened by Muslim (2020) who mentions the symptoms of stress during the Covid-19 pandemic as follows: (1) having excessive worry or fear so that they think irrationally, (2) having negative thoughts towards people who have signs sufferers of covid-19, (3) looking for excessive news about Covid19, causing anxiety which results in difficulty sleeping, and (4) feeling headaches and other physical ailments.

The results of the study Azmy, Nurihsan, and Yudha (2017) show that the emotional aspect is the highest aspect that affects the academic stress of gifted students, which is $48.60 \%$, so that students need special attention to manage academic stress through guidance and counseling programs. The impact of stress on individuals will cause difficulties in life management because stress will cause anxiety and the nervous system becomes less controlled (Sukadiyanto, 2010).

Based on the explanation above, it can be concluded that the stress experienced by physical education students when learning online greatly affects learning outcomes so this is considered important because this research has not been carried out before and there is no research result that describes the level of stress among students of physical education. Thus, the purpose of this study is to determine the stress level of physical education students during the Covid -19 pandemic. The stress level of physical education students needs to be known to prevent or overcome the occurrence of distress, manage stress so that physical education students can focus and concentrate while studying, and can keep learning motivation from decreasing. The results of this study are expected to be a reference in order to help reduce stress so that physical education students can learn well. 


\section{METHODS}

This research method is descriptive quantitative. The study population is all active physical education students in the Physical Education Study Program at the Islamic University of 45 Bekasi with an accidental sampling technique. Accidental sampling is a sampling technique based on chance (Anshori \& Iswati, 2017), physical education students who accept google form and are willing to fill out a questionnaire. Based on the sampling technique, a research sample of 168 respondents is obtained. In more detail, the number of research samples can be seen in the following table.

Table 1. Research Sample

\begin{tabular}{ccc}
\hline Semester & Respondents \\
\hline 2 & 29 & 48 \\
4 & 63 & 28 \\
6 & 168 \\
\hline Total & 16 \\
\hline
\end{tabular}

Data are collected using a questionnaire distributed via google form. The author distributes a questionnaire on May 8-11, 2020. The stress level measuring tool in this study is a questionnaire with a scoring system that would be filled in by respondents via google form. The author uses the Kessler Psychological Distresss Scale to assess stress levels during the Covid -19 pandemic. The Kessler Psychological Distresss Scale (K10) is a wellvalidated, ighly useful clinical measure of psychological symptoms noted for its ease of use, accessibility, high predictability, and high factorial and construct validity (Easton, Safadi, Wang, \& Hasson, 2017). That is, the Kessler Psychological Distresss Scale (K10) is a wellvalidated clinical measure of psychological symptoms and is well known for its ease of use, accessibility, high predictability, and high factorial and construct validity. Here are the 10 items the Kessler psychological distresss scale:

Tabel 2. The Kessler Psychological Distresss Scale

\begin{tabular}{cl}
\hline & \multicolumn{1}{c}{ In the past $\mathbf{3 0}$ days how often........} \\
\hline 1. & Did you feel tired out for no good reason \\
3. & Did you feel nervous \\
4. & Did you feel so nervous that nothing could calm you down \\
5. & Did you feel hopeless \\
6. & Did you feel so restless that you could not sit still \\
7. & Did you feel depressed \\
8. & Did you feel that everything was an effort \\
9. & Did you feel so sad that nothing could cheer you up \\
10. & Did you feel worthless
\end{tabular}

(Andrews \& Slade, 2001)

Before the questionnaire is distributed, the authors translate the standard questionnaire the Kessler psychological distress scale (K10) into Indonesian. Kessler Psychological Distresss Scale has been tested for reliability using Cronbach alpha and obtains a reliability index of 0.881 , while the value of vadility is above 0.2. The Kessler Psychological Distresss Scale consists of 10 questions that are asked to respondents with a score of 1 for the answers to never experiencing stress, 2 for the answers that rarely experience stress, 3 for the answers sometimes experiencing stress, 4 for the answers often experiencing stress, and 5 for answers always experiencing stress in the last 30 days. The measurement scale used is an ordinal scale (score 1-5). Stress levels are categorized as follows: 
Table 3. Stress Level Categories

\begin{tabular}{cc}
\hline Scores & Notes \\
\hline $20-24$ & Don't experience stress \\
$25-29$ & Mild stress \\
$>30$ & Moderate stress \\
& Severe stress \\
\hline
\end{tabular}

(Kakaje et al., 2021)

The data that has been collected is then processed. Data processing is intended as a process for obtaining summary data from raw data using certain methods or formulas (Hanief \& Himawanto, 2017). Data analysis in this study use quantitative descriptive analysis techniques with percentages. The formula used is as follows.

$$
\mathrm{P}=\frac{f}{N} \times 100 \%
$$

Information:

$\mathrm{P} \quad=$ Percentage sought

$\mathrm{f} \quad=$ frequency

$\mathrm{N} \quad=$ Number of respondents (Sudijono, 2008)

\section{RESULTS AND DISCUSSIONS}

The research sample consists of $82.7 \%$ male respondents (139 people), and $17.3 \%$ female respondents (29 people) with an age range of 18-26 years. The number of male respondents dominates in the study sample because most of the physical education students at the Universitas Islam 45 Bekasi are male.

\section{The overall stress level of physical education students during the COVID-19 pandemic}

Table 4. Overall Stress Level Categories for Physical Education Students during the Covid -19 Pandemic Period

\begin{tabular}{cccc}
\hline Scores & Amount & Persentage (\%) & Notes \\
$<20$ & 44 & 26.19 & Don't experience stress \\
$20-24$ & 32 & 19.05 & Mild stress \\
$25-29$ & 34 & 20.24 & Moderate stress \\
$>30$ & 58 & 34.52 & Severe stress \\
\hline Total & $\mathbf{1 6 8}$ & $\mathbf{1 0 0}$ & \\
\hline
\end{tabular}

Overall, it can be seen that during the Covid-19 pandemic, physical education students who did not experience stress were $26.19 \%$ (44 people), experienced mild stress by $19.05 \%$ (32 people), experienced moderate stress by $20.24 \%$ ( 34 people), and experienced severe stress by $34.52 \%$ ( 58 people). It can be seen that physical education students during the COVID-19 pandemic experienced the most severe stress with a percentage of $34.52 \%$ (58 people).

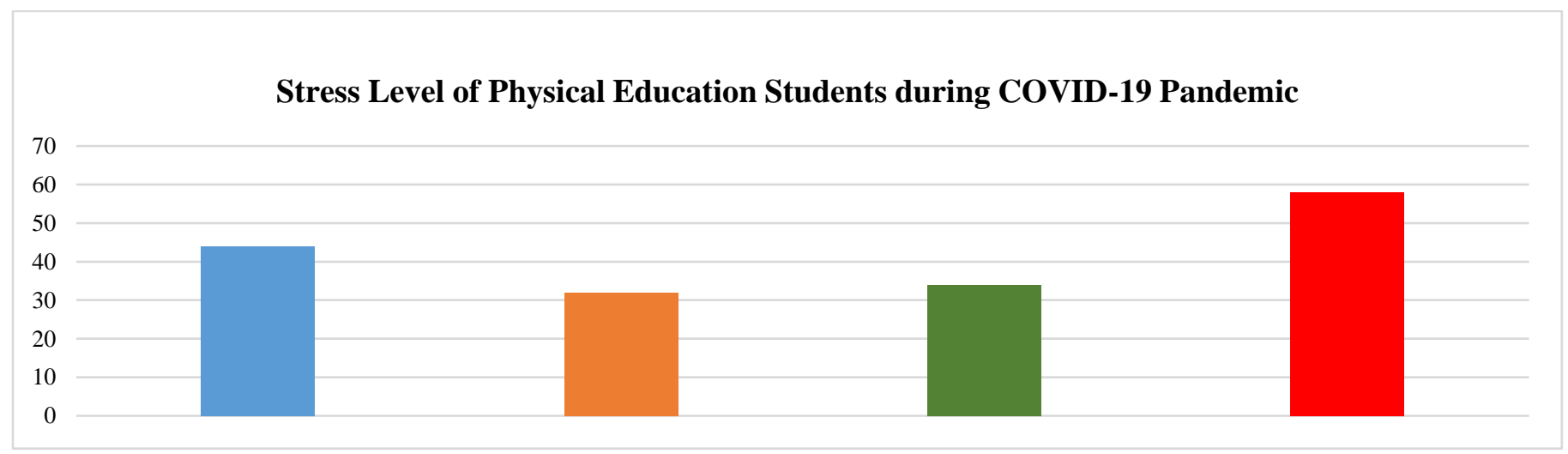

Figure 1. Graph of Physical Education Students Stress Level during the Covid-19 Pandemic Period 


\section{The stress level of second semester physical education students during the Covid-19 pandemic}

Table 5. Categories of Semester 2 Physical Education Students' Stress Level during the Covid-19 Pandemic Period

\begin{tabular}{cccc}
\hline Scores & Amount & Persentage (\%) & Notes \\
\hline$<20$ & 13 & 44.83 & Don't experience stress \\
$20-24$ & 3 & 10.34 & Mild stress \\
$25-29$ & 6 & 20.69 & Moderate stress \\
$>30$ & 7 & 24.14 & Severe stress \\
\hline Total & $\mathbf{2 9}$ & $\mathbf{1 0 0}$ & \\
\hline
\end{tabular}

In table 5 it can be seen that during the Covid-19 pandemic, second semester physical education students who did not experience stress were $44.83 \%$ (13 people), experienced mild stress by $10.34 \%$ ( 3 people), experienced moderate stress by $20.69 \%$ (6 people), and experiencing severe stress by $24.14 \%$ ( 7 people). It can be seen that the second semester of physical education students of Health and Recreation Physical Education during the Covid-19 pandemic did not experience stress at most with a percentage of $44.83 \%$ (13 people). More details can be seen in the following diagram.

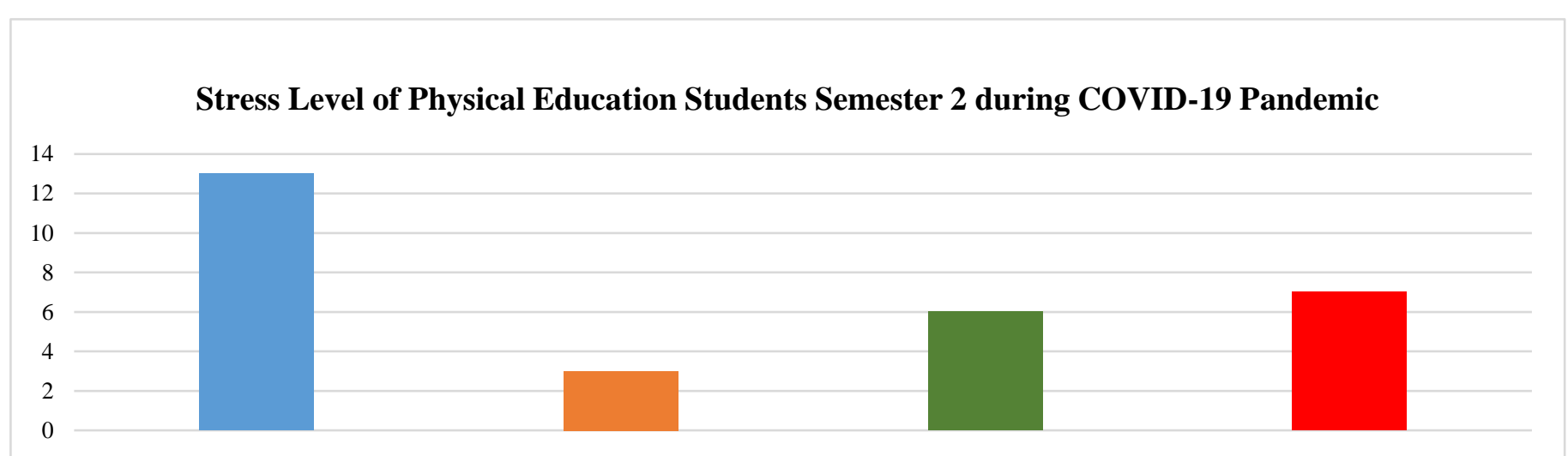

Figure 2. Graph of Semester 2 Physical Education Students Stress Level During the Covid-19 Pandemic Period

\section{The stress level of 4th semester physical education students during the COVID-19 pandemic}

Table 6. Stress Categories of Physical Education Students in Semester 4 during the COVID-19 Pandemic

\begin{tabular}{cccc}
\hline Scores & Amount & Persentage (\%) & Notes \\
\hline$<20$ & 11 & 22.92 & Don't experience stress \\
$20-24$ & 10 & 20.83 & Mild stress \\
$25-29$ & 9 & 18.75 & Moderate stress \\
$>30$ & 18 & 37.50 & Severe stress \\
\hline Total & $\mathbf{4 8}$ & $\mathbf{1 0 0}$ & \\
\hline
\end{tabular}

The table shows that during the COVID-19 pandemic, fourth semester physical education students who did not experience stress were 22.92\% (11 people), experienced mild stress were $20.83 \%$ (10 people), experienced moderate stress were $18.75 \%$ ( 9 people), and experiencing severe stress were $37.50 \%$ (18 people). It can be seen that the 4th semester of physical education students during the COVID-19 pandemic experienced the most severe stress with a percentage of $37.50 \%$ (18 people). 


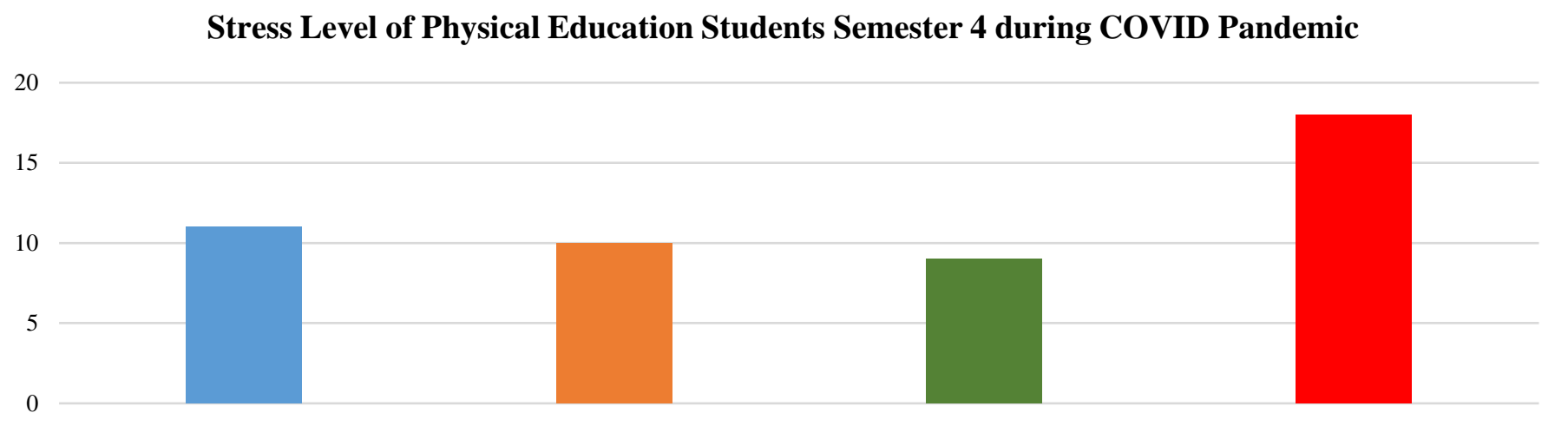

Figure 3. Graph of Semester 4 Students' Stress Levels During the Covid-19 Pandemic Period

4. The stress level of 6th semester physical education students during the COVID-19 pandemic

Table 7. Categories of Physical Education Student Stress Levels for Semester 6 during the COVID-19 Pandemic

\begin{tabular}{cccc}
\hline Scores & Amount & Persentage (\%) & Notes \\
\hline$<20$ & 13 & 20.63 & Don't experience stress \\
$20-24$ & 10 & 15.87 & Mild stress \\
$25-29$ & 14 & 22.22 & Moderate stress \\
$>30$ & 26 & 41.27 & Severe stress \\
\hline Total & $\mathbf{6 3}$ & $\mathbf{1 0 0}$ & \\
\hline
\end{tabular}

Based on the table above, it can be seen that during the COVID-19 pandemic, 6th semester physical education students who did not experience stress were $20.63 \%$ (13 people), experienced mild stress by $15.87 \%$ (10 people), experienced moderate stress by $22.22 \%$ (14 people), and experienced severe stress by $41.27 \%$ (26 people). It can be seen that the 6th semester of physical education students during the COVID19 pandemic experienced the most severe stress with a percentage of $41.27 \%$ (26 people).

Stress Level of Physical Eduation Students in Semester 6 during COVID-19 Pandemic

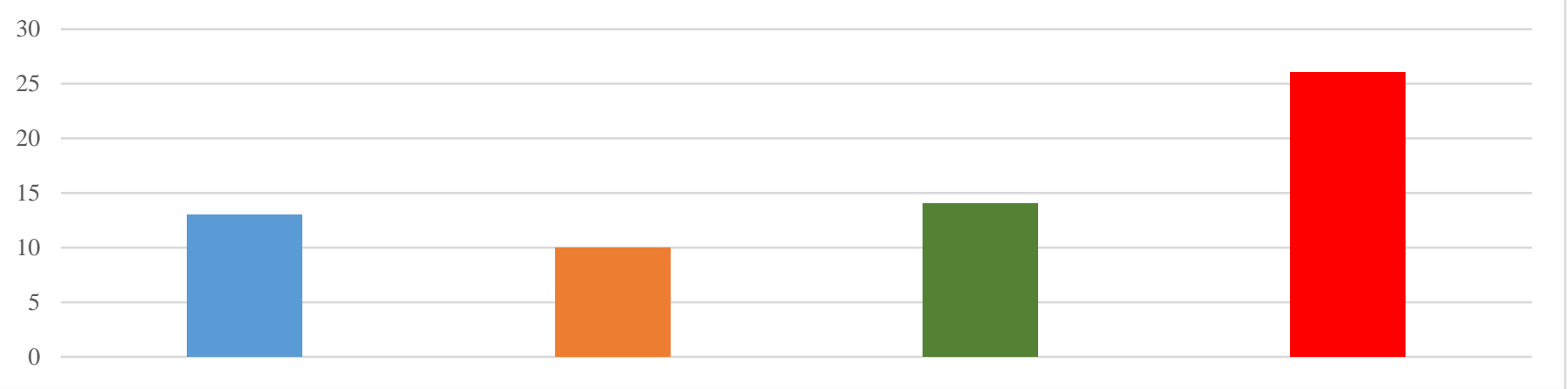

Figure 4. Graph of Physical Education Students' Stress Level in Semester 6 during the Covid-19 Pandemic Period

5. The stress level of 8th semester physical education students during the COVID-19 pandemic

Table 8. Categories of Physical Education Student Stress Level in Semester 8 during the COVID-19 Pandemic

\begin{tabular}{cccc}
\hline Scores & Amount & Persentage $(\boldsymbol{\%})$ & Notes \\
\hline$<20$ & 7 & 25.00 & Don't experience stress \\
$20-24$ & 9 & 32.14 & Mild stress \\
$25-29$ & 5 & 17.86 & Moderate stress \\
$>30$ & 7 & 25.00 & Severe stress \\
\hline Total & $\mathbf{2 8}$ & $\mathbf{1 0 0}$ & \\
\hline
\end{tabular}


Table 8 provides an overview during the COVID-19 pandemic period on 8 semester physical education students who did not experience stress were $25.00 \%$ (7 people), experienced mild stress were $32.14 \%$ ( 9 people), experienced moderate stress were $17.86 \%$ ( 5 people), and experiencing severe stress were $25.00 \%$ ( 7 people). It can be seen that physical education students in $8^{\text {th }}$ semester during the COVID-19 pandemic experienced the most mild stress with a percentage of $32.14 \%$ ( 9 people).

\section{Stress Level of Physical Education Students in 8th Semester during COVID-19 Pandemic}

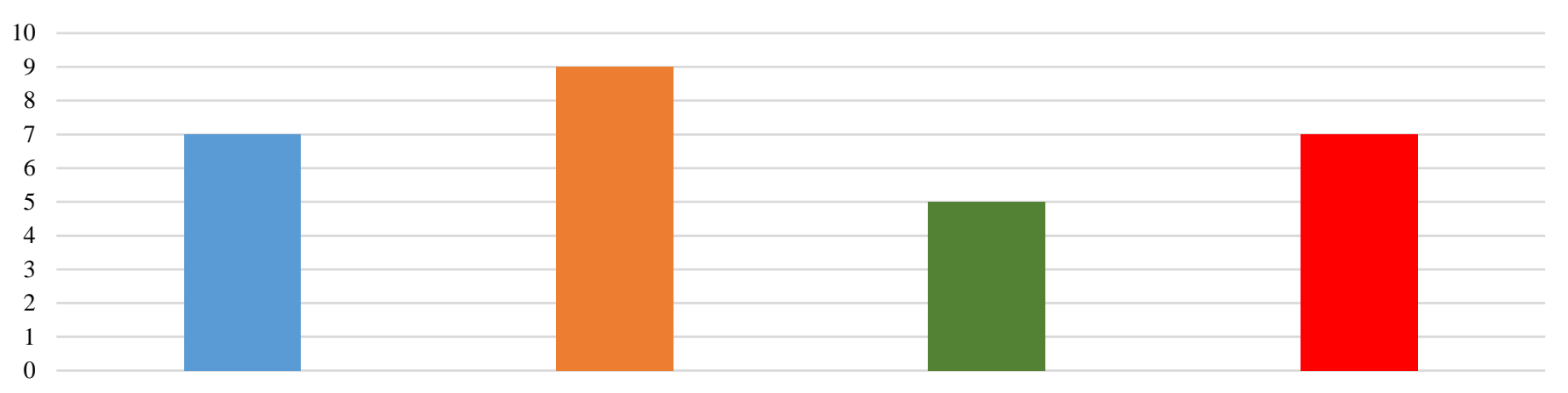

Figure 5. Graph of Stress Level of Physical Education Students in Semester 8 during the Covid-19 Pandemic Period

The results show that overall physical education students experienced severe stress during the COVID-19 pandemic. This is due to there has been a significant change in physical activity in physical education students who are increasingly becoming degenerative/lazy to move because of lockdowns and the LargeScale Social Restriction (PSBB) program. In an academic environment, stress is an experience most often experienced by students, whether studying at the school or college level due to the many academic demands that must be faced, for example exams, assignments, and so on (Gaol, 2016). If physical education students cannot manage stress and it occurs continuously without stopping, it will worsen the situation so that it has an impact on a distress condition, namely a negative reaction to stress. So, physical education students need to deal with stress so as not to become distress because it will affect psychologically and reduce interest in learning. The pressure faced by a person is not only caused distress, it can also be positive stress (eusstres) but requires mature mental control so that existing conditions become positive (Muslim, 2020). Lecturers also play an important role in helping students not to become stressed by creating variative, creative, and fun learning conditions.

After being examined more specifically, physical education students who experience the most severe stress are physical education students in semesters 4 and 6 . This is due to the courses taken are increasingly specific which have never been known before, so that physical education students have difficulty understanding learning material through lectures online. Meanwhile, the second semester of physical education students did not feel stressed because the subjects taken were still many general subjects, and sports practice had been obtained during high school. For final level physical education students (semester 8 ), the most experienced light stress, this is due to the courses taken are only final assignments (thesis). Physical education students experience light stress due to the uncertainty of the implementation of the thesis proposal seminar, thesis trial, difficulties in the guidance and revision process during the COVID-19 pandemic.

Based on the explanation above, stress can weaken the body's condition. A weak body condition can make it easier to transmit COVID-19. Therefore, physical education students must be able to manage stress so that their immune system is maintained. Stress management is usually associated with coping. Coping stress is an effort made by individuals to overcome problems that come to them (Subandy \& Jatmika, 2020). Adequate sleep, regular exercise, listening to music, making use of time effectively and efficiently by making schedules, doing recreation, telling problems that are being experienced with the closest people are 
also various ways to do stress management (Hariyanto, Dewi, \& Aini 2014). The purpose of stress management is to improve the quality of individual life for the better (Sari, Bulantika, \& Prasetyaning, 2020). Stress management that is not managed will cause student learning motivation to decrease (Alawiyah, 2020).

One way to manage stress for physical education students is to keep doing physical activity regularly. Physical activity cannot be separated from the influence of physical fitness (Safaringga \& Herpandika, 2018). The results of Prativi and Soegiyanto's research stated that sports activities have an effect on the level of physical fitness if done with a frequency of 3 times a week and a duration of 60 minutes (Prativi \& Soegiyanto, 2013). Physical activity is very important for physical education students, one of the benefits of doing physical activity is that it can improve brain performance in academic achievement (Donnelly et al., 2016).

During the COVID-19 pandemic, physical education students can still do physical activities at home or around the house. As is well known, currently there are many examples of physical activities that can be done by watching videos from YouTube, using training applications that can be downloaded on the mobile playstore, or tutorials from various social media that are equipped with uplifting music. Positive thinking can also be done by physical education students to learn to accept the situation they are facing during the COVID-19 pandemic so that they do not experience stress. Strengthened by Adriansyah et al who states that students who have positive thoughts in facing various conditions outside the expected, it will be easy to undergo and go through these conditions (Adriansyah, Rahayu, D., \& Prastika, 2015).

Physical education students can also do self-talk. Self talk is one of the techniques included in cognitive therapy (Ananda \& Apsari, 2020), so it must be done at the right time so as not to damage and disrupt concentration (Tangkudung \& Mylsidayu, 2017). Self-talk is what individuals say to themselves before, during, and after a certain situation (Simon, Bulantika, \& Prasetyaning, 2020). It's best to minimize the use of negative sentences when doing self-talk so that feelings don't turn negative (Hananto \& Hadi, 2020). Based on this description, self-talk can be carried out by students after waking up, ready to start activities in the morning, and before going to bed as a way to relieve stress.

Based on research results and supported by various relevant theories and research, tips / tricks in order physical education students can change stress into positive stress (eusstres) can do the following: (1) overcome stress (stress coping) by understanding theories and concepts of stress so that you can control yourself and your emotions, (2) manage and manage stress by recognizing yourself about your strengths and weaknesses, likes and dislikes, (3) doing physical activity regularly/routinely, (4) ) think positively so as not to raise anxiety (anxiety) which causes the nervous system to become less controlled, and (5) do self-talk as motivation to relieve stress.

\section{CONCLUSION}

Based on the exposure to the research results, it can be concluded that the stress level of physical education students during the COVID-19 pandemic experienced the most severe stress. Therefore, it is necessary to manage stress by coping with stress (stress coping), managing stress, doing physical activity, thinking positively, and doing self-talk. The limitation in this research is that this research does not represent a picture for all physical education students in Indonesia because the research respondents are only physical education students at Universitas Islam 45 Bekasi, and the research sample is dominated by male gender. For future researchers, they can conduct similar research with a larger sample so that the research results can be generalized in a broader scope.

\section{REFERENCES}

Adriansyah, M. A., Rahayu, D., \& Prastika, N. D. (2015). Pengaruh Terapi Berpikir Positif dan Cognitive Behavior Therapy (CBT) Terhadap Penurunan Kecemasan Pada Mahasiswa Universitas Mulawarman. Jurnal Psikostudia Universitas Mulawarman, 4(2), 105-125. 
Alawiyah, S. (2020). Manajemen stress dan motivasi belajar siswa pada era disrupsi. Al-Idarah: Jurnal Kependidikan Islam, 10(2), 211-221.

Ananda, S. S. D., \& Apsari, N. C. (2020). Mengatasi Stress Pada Remaja Saat Pandemi Covid-19 Dengan Teknik Self Talk. Prosiding Penelitian \& Pengabdian Kepada Masyarakat, 7(2), 248-256.

Andrews, G., \& Slade, T. (2001). Interpreting scores on the Kessler Psychological Distress Scale (K10). Australian and New Zealand Journal of Public Health. https://doi.org/10.1111/j.1467842X.2001.tb00310.x

Anshori, M., \& Iswati, S. (2017). Metodologi Penelitian Kuantitatif. Airlangga University Press.

Azmy, A. N., Nurihsan, A. J., \& Yudha, E. S. (2017). Deskripsi Gejala Stres Akademik dan Kecenderungan Pilihan Strategi Koping Siswa Berbakat. Indonesian Journal of Educational Counseling. https://doi.org/10.30653/001.201712.14

Barseli, M., \& Ifdil, I. (2017). Konsep Stres Akademik Siswa. Jurnal Konseling Dan Pendidikan. https://doi.org/10.29210/119800

Donnelly, J. E., Hillman, C. H., Castelli, D., Etnier, J. L., Lee, S., Tomporowski, P., Lambourne, K., \& Szabo-Reed, A. N. (2016). Physical activity, fitness, cognitive function, and academic achievement in children: A systematic review. In Medicine and Science in Sports and Exercise. https://doi.org/10.1249/MSS.0000000000000901

Easton, S. D., Safadi, N. S., Wang, Y., \& Hasson, R. G. (2017). The Kessler psychological distress scale: Translation and validation of an Arabic version. Health and Quality of Life Outcomes. https://doi.org/10.1186/s12955-017-0783-9

Hananto, D., \& Hadi, M. S. (2020). Pengaruh Teknik Self Talk Untuk Mengatasi Sikap Introvert Siswa. Jurnal Transformasi, 6(1), 12-16.

Hanief, Y. N., \& Himawanto, W. (2017). Statistik Pendidikan. Yogyakarta: Deepublish.

Hariyanto, D. D., Dewi, E. I., \& Aini S, L. (2014). Hubungan Persepsi tentang Kesesuaian Harapan Orang Tua dengan Diri dalam Pilihan Studi Lanjut dengan Tingkat Stres pada Siswa Kelas XII di Kabupaten Jember. Pustaka Kesehatan.

Kakaje, A., Al Zohbi, R., Hosam Aldeen, O., Makki, L., Alyousbashi, A., \& Alhaffar, M. B. A. (2021). Mental disorder and PTSD in Syria during wartime: a nationwide crisis. BMC Psychiatry. https://doi.org/10.1186/s12888-020-03002-3

Kemenkes RI. (2020). Pedoman Pencegahan dan Pengendalian Coronavirus Disease (COVID-19). Germas.

Komite Penanganan Covid-19 dan Pemulihan Ekonomi Nasional. (2021). Data Sebaran Kasus Covid-19 di Indonesia. https://www.covid19.go.id/

Kudielka, B. M., \& Wüst, S. (2010). Human models in acute and chronic stress: Assessing determinants of individual hypothalamuspituitaryadrenal axis activity and reactivity. In Stress. https://doi.org/10.3109/10253890902874913 
Gaol, N. T. L. (2016). Teori Stres: Stimulus, Respons, dan Transaksional. Buletin Psikologi, 24(1), 1-11. https://doi.org/10.22146/bpsi.11224

Lai, C. C., Shih, T. P., Ko, W. C., Tang, H. J., \& Hsueh, P. R. (2020). Ards COVID19. International Journal of Antimicrobial Agents, 7. https://doi.org/10.1016/j.ijantimicag.2020.105924

Legiran., Azis, M. Z., \& Belinawati, N. (2015). Faktor Risiko Stres dan Perbedaannya pada Mahasiswa Berbagai Angkatan di Fakultas Kedokteran Universitas Muhammadiyah Palembang. Jurnal Kedokteran dan Kesehatan, 2(2), 197-202.

Lian, J., Jin, X., Hao, S., Cai, H., Zhang, S., Zheng, L., ... \& Yang, Y. (2020). Analysis of epidemiological and clinical features in older patients with coronavirus disease 2019 (COVID-19) outside Wuhan. Clinical infectious diseases, 71(15), 740-747. https://doi.org/10.1093/cid/ciaa242

Muslim, M. (2020). Manajemen Stress Pada Masa Pandemi Covid-19. ESENSI: Jurnal Manajemen Bisnis, 23(2), 192-201.

Nebehay, S. (2020). WHO says it no longer uses "pandemic" category, but virus still emergency. Reuters. https://www.reuters.com/article/uk-china-health-who-idUKKCN20I0PD

Pascoe, M. C., Hetrick, S. E., \& Parker, A. G. (2020). The impact of stress on students in secondary school and higher education. International Journal of Adolescence and Youth, 25(1), 1-9. https://doi.org/10.1080/02673843.2019.1596823

Prativi, G. O., \& Soegiyanto, S. (2013). Pengaruh Aktivitas Olahraga Terhadap Kebugaran Jasmani. Journal of Sport Sciences and Fitness, 2(3), 32-36. https://doi.org/10.15294/JSSF.V2I3.3870

Putri, G. S. (2020). WHO Resmi Sebut Virus Corona Covid-19 Sebagai Pandemi Global. Kompas.Com. https://www.kompas.com/sains/read/2020/03/12/083129823/who-resmi-sebut-virus-corona-covid-19sebagai-pandemi-global

Rusdi, R. (2015). Hubungan Antara Efikasi Diri dan Manajemen Waktu Terhadap Stres Mahasiswa Farmasi Semester IV Universitas Mulawarman. EJournal Psikologi, 4(1), 53-64.

Sadikin, A., \& Hamidah, A. (2020). Pembelajaran Daring di Tengah Wabah Covid-19: (Online Learning in the Middle of the Covid-19 Pandemic). BIODIK, 6(2), 214-224. https://doi.org/10.22437/bio.v6i2.9759

Safaringga, E., \& Herpandika, R. P. (2018). Hubungan antara kebugaran jasmani dengan kualitas tidur. Jurnal SPORTIF: Jurnal Penelitian Pembelajaran, 4(2), 235-247. https://doi.org/10.29407/js_unpgri.v4i2.12467

Sari, P., Bulantika, S. Z., \& Prasetyaning, F. (2020). Pengaruh Manajemen Stress dan Kelola Emosi Terhadap Tingkat Kecemasan Siswa di Masa New Normal. Bulletin of Counseling and Psychotherapy, 2(2), 62-67.

Setiyawan, S., Kresnapati, P., \& Setiawan, D. A. (2020). Analisis perkuliahan daring mahasiswa PJKR Universitas PGRI Semarang sebagai dampak pandemi covid 19. Edu Sportivo: Indonesian Journal of Physical Education, 1(1), 25-32. https://doi.org/10.25299/es:ijope.2020.vol1(1).5148 
Simon, I. M., c, E. P. (2020). Paket pelatihan coping self-talk bagi calon konselor. Jurnal Pendidikan: Teori, Penelitian, dan Pengembangan, 5(4), 559-564. http://dx.doi.org/10.17977/jptpp.v5i4.13427

Subandy, K., \& Jatmika, D. (2020). Hubungan psychological capital dengan coping stress pada mahasiswa yang bekerja. Jurnal Psibernetika, 13(2), 68-82. http://dx.doi.org/10.30813/psibernetika.v13i2.2382

Sudijono, A. (2008). Pengantar Statistik Pendidikan. Jakarta: Grafindo Persada.

Sukadiyanto, S. (2010). Stress dan cara menguranginya. Jurnal Cakrawala Pendidikan, 1(1), 55-66. https://doi.org/10.21831/cp.v1i1.218

Tangkudung, J., \& Mylsidayu, A. (2017). Mental Training: Aspek-Aspek Dalam Psikologi Olahraga. Bekasi: Cakrawala Cendekia.

Wang, S., Kang, B., Ma, J., Zeng, X., Xiao, M., Guo, J., Cai, M., Yang, J., Li, Y., Meng, X., Xu, B., MedRxiv, M. C.-, 2020, U., Cai, M., Yang, J., Li, Y., Meng, X., \& Xu, B. (2020). A deep learning algorithm using CT images to screen for corona virus disease (COVID-19). MedRxiv. 1-9. https://doi.org/10.1101/2020.02.14.20023028

Xu, K., Cai, H., Shen, Y., Ni, Q., Chen, Y., Hu, S., ... \& Li, L. (2020). Management of corona virus disease19 (COVID-19): the Zhejiang experience. Journal of Zhejiang University (medical science), 49(1), 147-157. https://doi.org/10.3785/j.issn.1008-9292.2020.02.02 